\title{
RUSSIA AND THE RUSSIAN TOURIST IN FINNISH TOURISM STRATEGIES-THE CASE OF THE KARELIAN REGION
}

Katri JAKOSUO

Lahti University of Applied Sciences, Finland

\begin{abstract}
The Finnish travel sector needs more information about Russian tourists, because their importance has increased in Finland. In recent years, Russians have become the largest group of foreign tourists in Finnish accommodation establishments. For example, a total of 231,453 overnight stays were reported for Russian tourists in January 2011. This was almost 51 per cent of all overnight stays. Also, in 2009 the proportion of Russian tourists contributing to Finland's two-billion-euro income from international tourists was 31 per cent.

The main purpose of this study is to describe how Russia and Russian tourists have reacted to touristrelated strategies in Finland generally, and especially in Karelia, which is a Finno-Russian crossborder region. The qualitative research is based on official Finnish tourism strategies and the Karelia region's official tourism strategies $(n=5)$.

According to the results, one of the advantages of Finland is its close proximity to Russia, which means easy access for Russian tourists. The main strategic goal in Finland generally and especially in the Karelia region, is to extensively exploit Russia's markets and the purchasing power of Russians. The strategic goals emphasise such things as infrastructure, services development and co-operation between the different actors in Finland and Russia. Knowing the mutual history of Finland and Russia is remarkable that Russian tourists are mentioned by name in tourism strategies.
\end{abstract}

Keywords: Russia, Russian, service management, tourism, tourists

\section{INTRODUCTION}

Finnish people tend to think differently than Russians. Before Finland gained independence in 1917, it had been a part of the Russian Empire for 108 years. In the middle of the 20th century Finland fought the Winter War and the Continuation War against the Soviet Union. As a result of the wars, Finland lost, for example, most of the province of Karelia (Map 1).

According to Andersen (2003), when a Finn and a Russian say "Karelia" they often mean two different areas. For the Finnish people Karelia (Karjala) means the region "Karelia" shown on the left in Map 1. This region was part of the Swedish-Finnish Kingdom from 1323/1617 to 1721/1743, part of the Grand Duchy of Finland between 1809 and 1918 and part of independent Finland 1918-1939 and 1941-1944. As a result of World War II, most of what Finnish people define as Karelia was incorporated into the USSR to become parts of the Leningrad oblast' and the semi-autonomous "Karelian Republic", its population having withdrawn to Finland. As of today, the region still remains in the Russian Federation. For Russians Karelia usually means the "Republic of Karelia", which is a federal subject of Russia. This region is shown in Map 1 as "East Karelia". Most of this territory has traditionally been under Russian influence. (Andersen 2003.)

Nowadays South Karelia consists of 12 municipalities and two cities (Lappeenranta and Imatra) and North Karelia consists of nine municipalities and five cities (Joensuu, Kitee, Lieksa, Nurmes and Outokumpu). The distance from Lappeenranta and Imatra to St Petersburg is about 210 kilometres. In the Karelian region, there are about 2,000 lakes and two thirds of the area is covered by forest. There are also three national parks and numerous Orthodox churches and chapels. In the South Karelia region there is a transportation canal, which connects Lake Saimaa to the Gulf of Finland (43 km). This canal is an administratively special part of Russia for which reason there are also special regulations for vessels travelling to Finland through the canal. (Visit Karelia 2011.) Although the forest industry employs many people, North Karelia's rate of unemployment (14.7\%) is nevertheless one of the biggest in Finland (average 7.9\%). (Statistics Finland 2011a.) 

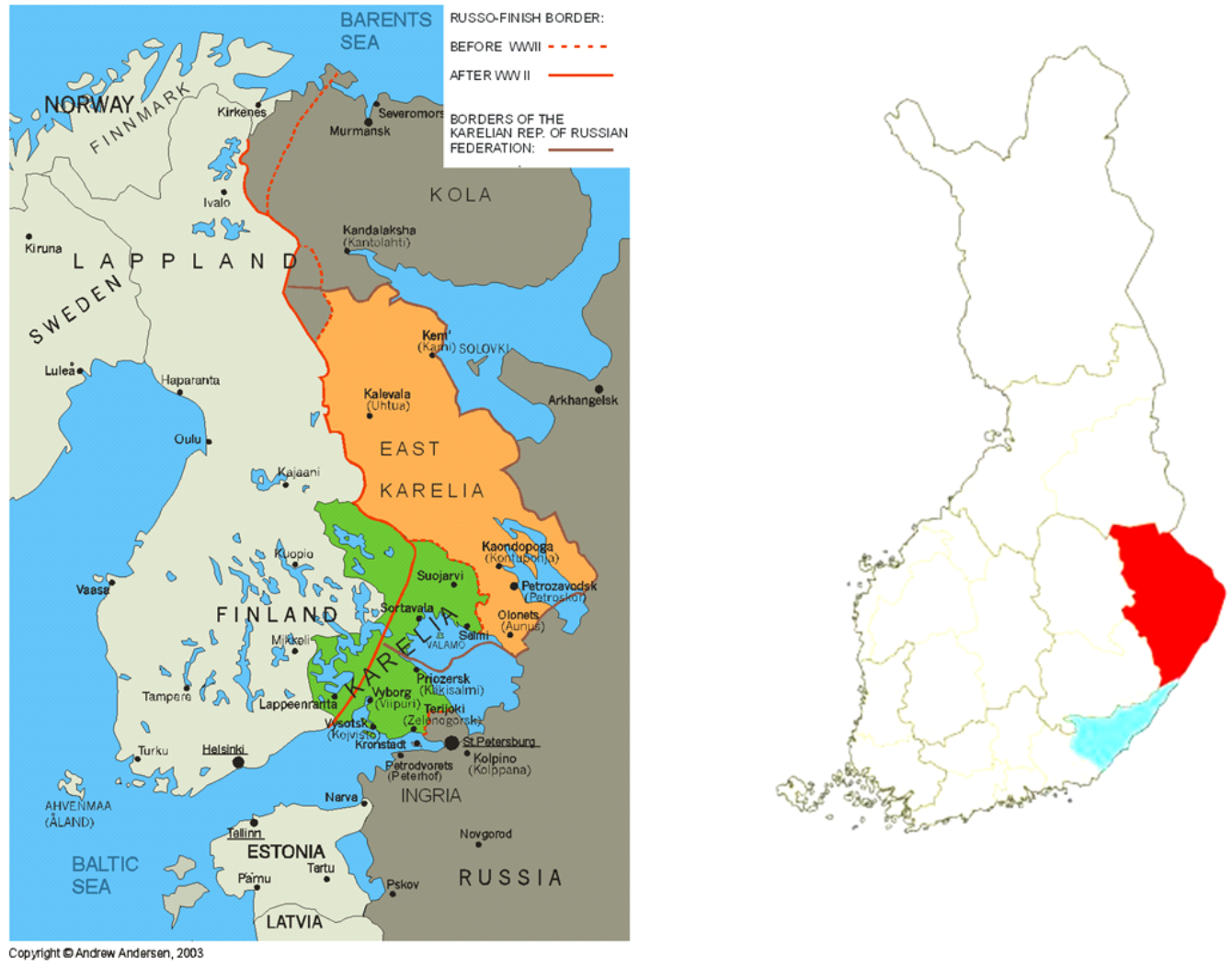

\section{Map 1. Map of Finland and Karelia Region (Andersen 2003; Wikipedia 2011a; 2011b)}

Today Russia, with 140 million inhabitants, provides a huge potential market for the Finnish tourist trade. In the St Petersburg region alone, which lies near the Finnish border area, there are about 4.6 million inhabitants. This is almost equivalent to the entire Finnish population. Because of this, Russians are nowadays an important part of the Finnish tourist trade. According to the Bank of Finland (2010), in 2009 the proportion of Russian tourists contributing to Finland's two-billion-euro international tourist industry was 31 per cent.

The purpose of this study is to describe how Russia and Russian tourists have reacted to tourist-related strategies in Finland generally and Karelia in particular, which is a cross-border region. This study is limited to observing those goals and actions which are related to Russia and the Russian tourist.

\section{LITERATURE REVIEW}

Among the benefits of strategic management are, for example, a clearer sense of strategic vision, sharper focus on what is strategically important and an improved understanding of a rapidly changing environment. A strategy consists of purposes, policies, programmes, actions, decisions, and/or resource allocations that define what an organisation is, what it does, and why it does it. Strategic decisions deal with the "big" things, covering multi-functional service areas and the long-term focused on innovation and core functions, and take into consideration the need for cultural change in order to create a business friendly environment. Strategy is essentially an emergent phenomenon, involving the crafting of a corporate culture through reviews of the organisation's present state, and formation of a mission and vision to guide its future development. (Dereli 2003, 253; Wheelen \& Hunger 2006, 5.) The tourist industry is usually seasonal and strategies must therefore help regions to focus on their resources and increase local income from tourism throughout the year.

\section{Tourism as an Industrial Sector}

Tourist services consist of different elements, such as transportation, accommodation and activities at the place of destination. One of the major challenges is to integrate these services, resources, core competences and capabilities, so that the customer is rewarded with an unforgettable travel experience. (Chen, Chen, Ho \& Lee 2009, 326.) The tourist sector is labour intensive and often provides 
work for young adults. The problem is that this sector suffers from the seasonality of tourism, and seasonality has usually limited the economic contribution that tourism can make to the local economy (Font, Tapper \& Cochrane 2006, 53-54).

Sharma and Dyer $(2009,358-359)$ have listed several positive effects of tourism. Tourism increases, for example, employment, investments and tax revenues and demands the maintenance of high standards for roads and public facilities. It also encourages the development of a variety of cultural activities by local residents aimed at creating a positive impact on the cultural identity of the community.

As in any industrial sector, so in the tourism industry, the economic, social and technological factors, for example, affect the operational environment.

\section{Infrastructure and Investment}

The tourist trade must have a multifarious infrastructure, including accommodation, restaurants, attractions, tours and transport connections. In many cases these are primarily developed by the private sector. Without basic services (e.g. energy, water, electricity and telecommunications) and a suitable road, rail and air infrastructure, private investment will be unwilling to provide fiscal support for tourist facilities. Also, a well-designed infrastructure supports and attracts tourists and brings revenue to the local actors. (Brooker \& Burgess 2008.)

According to Stokes $(2005,689)$, there is a link between the perceived purposes of investment and government policies related to tourism. For example, if tourism is part of business policy, it will be easier to attract private investors. Also, those activities and investments supporting local food and craft production can be very beneficial financially to the regional economy (Font, Tapper \& Cochrane 2006 ,

\section{Actors and Cooperation}

Generally the supply chain consists of the suppliers of all the products and services that go into the delivery of products/services to customers. Tourism supply chains involve many components, not just accommodation, transport and excursions, but also for example restaurants, handicrafts, waste disposal and the infrastructure that supports tourism at the destinations. Successful supply chain relationships between different enterprises and other actors consolidate the common view about goals. Also, the policy and management systems of the local authority have to support goal achievement.

According Ateljevic $(2008,284)$, local authorities may play a proactive role when investing in tourist facilities, encouraging co-operation between different actors and establishing regional networks. Besides local authorities and NGOs there are many actors in the tourist sector, such as accommodation, tour and restaurant enterprises. So, as far as regional development view is concerned, it is important that networks are as multiperspective as possible. Cooperation between the local authorities and NGOs, business and other organisations assists all local actors in the region (Contini, Scarpellini \& Polidori 2009, 35). Further, Pechlaner, Raich and Fischer (2009, 28-29) have shown the importance of cross-sector cooperation as well as the potential role of tourist organisations in an integrated location management system.

\section{Marketing and Customer-oriented Approach}

Marketing is one way to achieve strategic goals and support the regional identity (Hwang \& Lockwood 2006, 341; Sharma \& Dyer 2009, 355). Furthermore, tourist enterprises and destinations have become aware that they need to redefine their strategies in order to respond effectively to operational environment changes such as the heterogeneity of consumers' needs, motivation and behaviours, and the changing face of global economic and social conditions. According to Riege and Perry's model, the tourist trade has proposed three strategic approaches, which are 1) the consumer-oriented approach, 2) the competitor-oriented approach and 3) the trade-oriented approach. The first approach refers to the use of a differentiated (target marketing) or undifferentiated marketing strategy depending on market conditions. The second approach focuses on competition where the role of marketing is to develop, maintain or defend the position of a tourist organisation. The trade-oriented approach focuses on intermediaries and it might be more relevant to the travel and tourist industry. According to this approach, the distribution of travel and tourist products/services is the most important activity along the tourism chain. (Tsiotsou \& Ratten 2010, 538.)

Hwang and Lockwood $(2006,342)$ noticed that it is important to know the customer so that target markets can be clearly identified and selected and the marketing mix managed properly. This knowl- 
edge is also important for networking, because if the goals of enterprises are not clear, this might be a barrier to effective partnering and networking. They suggest that for success enterprises have to, for example, know their customers, develop detailed service standards for each market segment and know their competitors.

Nowadays the most important areas in tourism marketing are branding, consumer behaviour, emarketing and strategic marketing. Especially have e-marketing and new technologies (e.g. mobile services such as mobile TV, mobile WEB and Web 2.0) become more significant. (Tsiotsou \& Ratten 2010, 537.) Despite these different new marketing channels, tourism service providers still need to understand the customer and increase perceived customer value by creating suitable products. The adoption of new technologies, innovative services and experiences can be designed, developed, and delivered to create higher perceived customer benefits. (Chen, Chen, Ho \& Lee 2009, 334.) In the international tourist sector cultural knowledge, cross-cultural and language skills are an important part of product and service development (Jakosuo 2008). Without these skills it is almost impossible to serve multinational customers. For example, Hwang and Lockwood $(2006,348)$ have shown that communication between staff and customers can be problematic due to language and culture differences.

Where tourist strategies are concerned the segmentation criteria for customers will usually be, for example, the use of services, demographic factors and geographical factors related to destinations. Even if there are different customer segments in Finnish strategies international tourists normally form only a one group. The exception is Russian tourists.

\section{Russian Tourists in Finland}

The Finnish tourist industry has remarkable multiplicative effects on the national economy. In 2007, tourism accounted for 2.3 per cent of Finland's GDP, while the share of tourist businesses was 3.8 per cent. However, in terms of employment and tax revenue for the national economy, tourism is a larger industry in relative terms. The tourist industry provides work for 130,500 people. This means that about five per cent of employees earn their living in the tourist sector. In the private service sectors, over one tenth of workers are employed by tourist businesses. The portion of government taxes and tax-related fees is about five per cent. (Ministry of Employment and the Economy 2010, 6, 8.)

In recent years Russians have become the largest group of foreign guests in Finnish accommodation establishments. For example, a total of 231,453 overnight stays were reported for Russian tourists in January 2011. This was almost 51 per cent of all overnight stays. Also, in 2009 the proportion of Russian tourists contributing to Finland's two-billion-euro income from international tourists was 31 per cent. (Bank of Finland 2010; Statistics Finland 2010; 2011b.)

The global recession had a negative effect on the Finnish tourist industry. For example, in 2009 travel from EU countries to Finland declined 12 per cent and Finland's income from international tourism dropped seven per cent. At the same time the number of those arriving in Finland from Russia declined by only five per cent and revenue from Russian tourists declined by a mere four per cent. Between 2000 and 2009, the number of Russian tourists staying overnight grew the most, from around 450,000 to slightly less than 800,000 . (Statistics Finland 2009.)

The meaning of Russian tourists has increased significantly in the Karelia region in particular: for example, whereas in 2004 Russian tourists spent 12 million euros in Imatra and 70 million in Lappeenranta, in 2010 they spent 62.5 million euros and 196.7 million in these two cities respectively. Also, the structure of consumption has changed: in 2004 the proportion of services was 9.8 per cent, whereas in 2010 the proportion had risen to 19.2 per cent. (TAK 2005; 2011.) Further, the latest news lends support to the finding that Russian tourists spent more money than other international tourists. For example, University of Eastern Finland (2011), Russian tourists spent 101 euros per day, whereas tourists from Finland and other EU countries at the same time spent 88-94 euros per day in the Savonlinna region, which is adjacent to Karelia.

There are many factors that influence interest groups and local residents' attitudes towards tourism, such as the type of tourism and tourists (Cooper, Fletcher, Gilbert, Shepherd \& Wanhill 1999, 113). In Finland, and especially in the Karelian region, Fenno-Russian history has had its own effect. Not surprising then that there are some residents and some local enterprises who take a negative attitude towards Russians. It is worth noting that the myth that Russians are the arch enemy of Finland began between the world wars. Before that the relationship between the Finns and Russians was good, even though the languages and culture were different. However, the wars changed all that and for example in 1939-1944 one form of Finnish war propaganda was to disseminate negative information about the 
Russians. This negative information resulted in so-called russophobia. Even now decades after the wars, Finns rate the Russians below average compared to other Europeans. (Ollus \& Simola 2006; Vihavainen 2006, 323.) Additionally, cultural and linguistic problems complicate relations: unlike the Finns, Russians use the Cyrillic alphabet, and in Russia the rhythm of life and concept of time are different (Jakosuo 2008, 4-6; 2009; 2010, 8).

Attitudes are changing slowly, and especially during the global recession several Finnish actors in the tourist industry began to take note of the meaning of Russia and Russian tourists. Those in the Karelian region have also noticed the importance of our eastern neighbour, with the result that now Russia and Russian tourists have become an essential part of the Finnish tourist industry.

\section{DATA AND METHODS}

The analyses and the findings are based on official Finnish tourism strategies and the Karelia region's official tourism strategies. The study is limited to observing only those goals and actions which are related to Russia and the Russian tourist. A summary of the textual data is shown on Table 1.

Table 1. Summary of the Textual Data

\begin{tabular}{|l|l|l|l|l|}
\hline Author & Year & Region & Period & Notes \\
\hline $\begin{array}{l}\text { Ministry of Employment } \\
\text { and the Economy }\end{array}$ & 2010 & Finland & $2011-2020$ & $\begin{array}{l}\text { Strategy includes reasons to promote } \\
\text { tourist industry development }\end{array}$ \\
\hline $\begin{array}{l}\text { Central Karelia Develop- } \\
\text { ment Company }\end{array}$ & 2010 & $\begin{array}{l}\text { North } \\
\text { Karelia }\end{array}$ & $2011-2014$ & $\begin{array}{l}\text { Central Karelia is part of the North } \\
\text { Karelia Region }\end{array}$ \\
\hline $\begin{array}{l}\text { Regional Council of North } 2007 \\
\text { Karelia }\end{array}$ & $\begin{array}{l}\text { North Ka- } \\
\text { relia }\end{array}$ & $2007-2013$ & $\begin{array}{l}\text { Preceding strategy is from 1996 to } \\
2006\end{array}$ \\
\hline $\begin{array}{l}\text { Regional Council of South } 2006 \\
\text { Karelia }\end{array}$ & $\begin{array}{l}\text { South Ka- } \\
\text { relia }\end{array}$ & 2006-2015 & $\begin{array}{l}\text { Strategy is a contract between differ- } \\
\text { ent actors (e.g. regional council) }\end{array}$ \\
\hline $\begin{array}{l}\text { Ministry of Trade and In- } \\
\text { dustry }\end{array}$ & 2006 & Finland & $2007-2013$ & $\begin{array}{l}\text { Strategy includes the vision 2020 and } \\
\text { the action plan 2007-2013 }\end{array}$ \\
\hline
\end{tabular}

This research is based on qualitative research, which is useful for studying a limited number of cases in depth and it provides individual case information. Also, a qualitative approach is well suited for analysing local situations and conditions. Despite this, qualitative research has several drawbacks (e.g. its subjectivity and lack of generalisation). Because the researcher selects the data and makes choices between different sources, the data can never be perfect. Also, the amount of data is typically smaller than in a quantitative analysis, for which reason qualitative data only provides a snapshot view of the phenomenon. The data are used to describe, rather than explain, the phenomenon. (Ramos, Salazar \& Gomes 2000; Yin 2003.) This textual data is considered in the light of content analysis. According to Silverman (1997), the content analysis is an accepted method of textual investigation. The method involves establishing categories and then counting the number of instances in which those categories are used in a particular item of text.

\section{RESULTS}

The goal of Finland's tourism strategy is to create the prerequisites for the development, growth and competitiveness of year-round tourism and the related business operations. In Finland tourism is a significant source of employment and it helps Finland's economy to expand. Also, tourism is significant factor as a source of regional livelihood. (Ministry of Employment and the Economy 2010, 34.)

In the Karelia region the main strategic goals are to widely utilise Russia's markets and Russians' purchasing power. The future visions include ensuring that the proportion of Russia trade is significant, that Russians invest in Finland and that tax-free sales increase. Among other things, the North Karelia region anticipates that tax-free sales will reach ten billion euros by 2015. (Council of South Karelia 2006, 7-8; Regional Council of North Karelia Regional 2007, 9.)

It is of note concerning Russia that Finland's Tourism Strategy since 2006 only states that Russia will be one of the main marketing areas and a competitor in the future. Apart from this, there is no mention of Russia or Russian tourists (Ministry of Trade and Industry 2006, 17, 22, 89). 


\section{Strengths and Weaknesses}

According to Finland's Tourism Strategy, one of the strengths of Finland is easy accessibility from Russia and particularly St Petersburg and the adjacent areas. Russians already form the largest foreign customer group in Finland, and the potential for increasing the number of tourists is huge. Russia does not have connections to any other country which are as good and quick as these, and the high-speed Helsinki-St Petersburg rail link will enhance Finland's competitiveness even further in terms of attracting Russian tourists (the travel time from Helsinki to St Petersburg is 3.5 hours). The other strengths are, for example, attractive travel destinations/tourism areas and the diverse services offered by tourism clusters. (Ministry of Employment and the Economy 2010, 15-16.)

According to my results, Finland is an attractive travel destination with beautiful nature and the Karelia region has willingness to develop. One of the main strengths in Finland and the Karelia region is a unique location next to Russia. On the other hand, one of the main weaknesses is accessibility. Viewed from parts of the world other than Russia, Finland is an island. Indeed, distances from other, non-Russian, parts of the world are longer than in the case of competing countries, and this raises travel costs. The other weaknesses are generally high prices in Finland and lack of investment, cooperation and coordination in the Karelia region.

\section{Development Proposals}

All strategies contain several proposals. These can be further classified into five big sectors, which are 1) administration, 2) infrastructure, 3) cooperation 4) marketing and 5) tourist services development. This classification is based on observations in the literature review.

First, all of the Karelia region's strategies contain suggestions which are related to administration. According to these strategies, it would be very important to extend the visa-free regime and develop the Niirala border crossing point area. Additionally, South Karelia's strategy includes suggestions regarding the importance of developing cross-border education, business advisory services and cooperation between the Finnish and Russian labour force authorities. One of the goals of North Karelia's strategy is to encourage tourism investments so that the travel concentrations grow and international competitiveness increases. (Council of South Karelia 2006, 4; Regional Council of North Karelia Regional 2007, 8; Central Karelia Development Company 2010, 17.)

Strategies state that the infrastructure must be reinforced and developed. For example, the North Karelia regional strategy mentions that it is important to develop land use, town planning and road networks between Finland and Russia. In this way it should be possible to increase Russian investment in North Karelia. One advancement concerning the infrastructure is the rapid rail link between Helsinki and St Petersburg opened in January 2011. This rapid rail link is improving Finland's image as an attractive destination for Russian travellers. (Council of South Karelia 2006, 11; Central Karelia Development Company 2010, 17.)

Furthermore, according to the strategy announced by the Council of South Karelia $(2006,9)$, one of the main strengths of this area is the unique Saimaa canal, which connects Lake Saimaa with the Gulf of Finland. Canal cruises are very popular with Russian tourists. At present, Russian visas are not required for simply passing through the canal, but a passport is needed and it is checked at the border. A visa-free regime would simplify accessibility from Russia to Finland.

In all strategies one of the main goals is to develop cooperation and networks between local actors in Finland and between Finnish and Russian actors. The strategies suggest that provinces will have to increase tourism cooperation between different provinces and local actors in Finland. The strategies of the Regional Council of North Karelia $(2007,12)$ and the Central Karelia Development Company $(2010,8)$ emphasise that is important to find a common view on marketing and developing models.

Proposals for developing marketing are also mentioned in the strategies. These strategies recommend that the Karelia region should develop both local and international (Russia) marketing through different channels (e.g. e-marketing). Along with brochures, internet marketing could be used. Also, one channel could be an information centre for Russian tourist agencies in St Petersburg. (Council of South Karelia 2006, 7-8; Regional Council of North Karelia 2007, 12; Central Karelia Development Company 2010, 7.) 
Finally, there have also been some proposals concerning services development. These strategies suggest that the provinces have to develop tourism around Lake Ladoga in collaboration with Russia, create concepts of short break holidays and accommodation, food and events, and develop further cooperation, for example, in cultural and sports events between Finland and Russia. (Council of South Karelia 2006, 8-10; Regional Council of North Karelia 2007, 16; Central Karelia Development Company 2010, 17.)

One interesting point is that South Karelia plans to build a museum to commemorate the battle of Tali -Ihantala (Regional Council of North Karelia 2007, 9). This battle (June 25 to July 9, 1944) was the largest battle in the history of the Nordic countries and it was fought between the Finnish and Soviet armed forces. After the battle the Finnish army reported that about 8,350 men had been wounded, missing and/or killed in action and the Soviets reported their losses at about 28,000 wounded, missing and/or killed. (Raunio, Ahonen \& Hagan 1994.)

Finland has also noticed the importance of cultural knowledge. The Central Karelia Development Company's $(2010,5,7)$ strategy suggests that the provinces can increase cultural awareness by making use of those people who have moved from Russia to Karelia. Consistently the strategy of the Regional Council of North Karelia $(2007,13)$ mentions that it is important that Russian tourists can do business in their own language. Finland's Tourism Strategy suggests that educational institutions in the tourist and restaurant trade should therefore focus more directly on teaching the Russian language and culture. (Ministry of Employment and the Economy 2010, 15, 21.)

\section{DISCUSSION AND LIMITATIONS}

The main purpose of this study is to describe how Russia and Russian tourists have reacted to touristrelated strategies in Finland generally and Karelia in particular, which is a cross-border region. My qualitative examination is based on official Finnish tourism strategies and those of the Karelia region $(\mathrm{n}=5)$. These strategies were published between 2006 and 2010 .

The main result is that at present Russia and Russian tourists take into account Finland's and the Karelia region's strategies in many ways. There are several multilevel development proposals, from the development of the road and rail infrastructure and the extension of the visa-free regime to sport events, to the development of language skills.

Figure 1 is a summary of tourism strategies. These tourism strategies are based at least partially on differentiation, because the strategies take into account the Russian tourists (e.g. Tsiotsou \& Ratten 2010, 538). Strategic planners have noticed that tourism needs a multifaceted infrastructure and it should be part of the regional business policy. They have also noticed that the role of the local authorities is very important in regional development and also the importance of cooperation between the different actors (e.g. in investment). These results support corresponding findings in the literature review (Stokes 2005, 289; Ateljevic 2008, 284; Brooker \& Burgess 2008; Contini, Scarpellini \& Polidori 2009). 
Figure 1. Summary: Russia and the Russian Tourist in Finnish Tourism Strategies

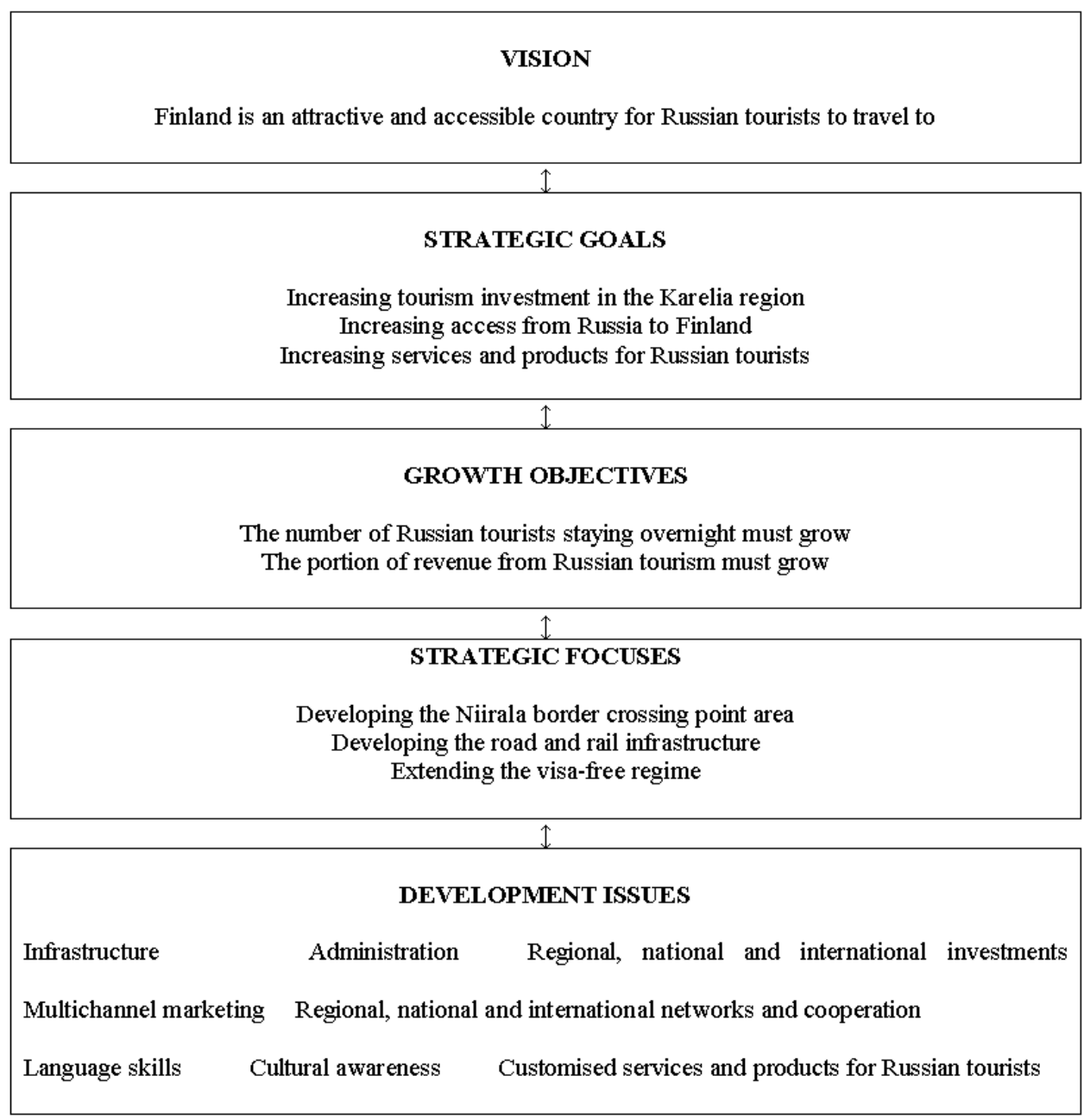

What is more, the strategies take a stand on marketing and cultural awareness. E-marketing and strategically focused marketing would support these strategies. According to Tsiotsou and Ratten (2010, 537), these elements are the most important areas in tourism marketing. Hwang and Lockwood's (2006, 348) opinion is that cultural knowledge is an important part of action. In the strategies of Finland and the Karelia region cultural awareness is taken into account in, for example, those proposals which concern language and communication skills. These skills also help improve customised services and products for Russian tourists. Despite all this, it is nevertheless important to know your competitors, and yet no competitive environment was specified by the strategies (e.g. Hwang \& Lockwood 2006, 342).

The principal limitations of this study concern three aspects: the scope of the study, the simplicity of the data and the age of the data. First, this study was carried out mainly in the context of the governmental authorities. Therefore, this means that the opinion of private sector actors is less significant. Second, because the data consisted of only five strategies, these data represent only a small part of the local tourism supply chains' view and a generalisation of the results is quite impossible. As far as the literature review goes, the problem is that there have not yet been any similar studies. It is rare for only one ethnical group to be mentioned by name in tourism strategies. Finally, some of the strategies are almost five years old and these were made in a different economic environment before the recession. On the other hand, according to today's Finnish media, Russian tourists still play an important part in Finnish tourism. 


\section{REFERENCES}

Andersen, A. (2003), What is Karelia?, http://conflicts.rem33.com/images/Finland/ wat_is_karjala.htm.

Ateljevic, J. (2008), Tourism entrepreneurship and regional development: Example from New Zealand,

International Journal of Entrepreneurial Behaviour \& Research, 15 (3), pp. 282-308.

Bank of Finland - Institute for Economies in Transition. (2010), Venäjä, Viikkokatsaus, 38, pp. 1.

Brooker, E. \& Burgess, J. (2008), Marketing destination Niagara effectively through the tourism life cycle, International Journal of Contemporary Hospitality Management, 20 (3), pp. 278-292.

Central Karelia Development Company. (2010), Central Karelia's business strategy, Updating 20112014, Central Karelia Development Company KETI Ltd.

Chen, Y. G., Chen, Z-H., Ho, J.C. \& Lee, C-H. (2009), In-depth tourism's influences on service Innovation. International Journal of Culture, Tourism and Hospitality Research, 3 (4), pp. 326-336.

Contini, C., Scarpellini, P. \& Polidori, R. (2009), Agri-tourism and rural development: The LowValdelsa case, Italy, Tourism Review, 64 (4), pp. 27-36.

Cooper, C., Fletcher, J., Gilbert, D., Shepherd, R. \& Wanhill, S. (1999), Tourism: Principles and practice, 2nd edition, Addison Wesley Longman Publishing, New York, USA.

Dereli, C. (2003), Strategy and strategic decision-making in the smaller local authority, International Journal of Public Sector Management, 16 (4), pp. 250-260.

Font, X., Tapper, R. \& Cochrane, J. (2006), Competitive strategy in a global industry: Tourism, Handbook of Business Strategy, 7 (1), pp. 51-55.

Hwang, L-J. \& Lockwood, A. (2006), Understanding the challenges of implementing best practices in hospitality and tourism SMEs, Benchmarking: An International Journal, 13 (3), pp. 337-354.

Jakosuo, K. (2008), Selvitys metropolialueen venäläismatkailijoista, Lahden ammattikorkeakoulun Matkailun laitos.

Jakosuo, K. (2009), Venäläiset matkailijat Metropolialueella, In: Jakosuo, K. \& Jaakkola, L. (ed.) 2009. Kasviretkestä kokouspalveluihin - Artikkelikokoelma matkailualan kehittämishankkeista ja opinnäytetöistä, pp. 24-28, Lahden ammattikorkeakoulun julkaisusarja C. Tampereen Yliopistopaino, Tampere, Finland.

Jakosuo, K. (2010), Lomatoiveena shoppailun lisäksi saari, sauna ja vene - Kyselytutkimus Suomessa keväällä 2009 vierailleille venäläisille matkailijoille, Lahden ammattikorkeakoulun Matkailun ala.

Ministry of Employment and the Economy. (2010), Finland's tourism strategy to 2020: Four good reasons to promote tourist industry development, the Finnish Tourist Board/Visit Finland, Helsinki, Finland.

Ministry of Trade and Industry. (2006), Suomen matkailustrategia vuoteen 2020 \& Toimenpideohjelma vuosille 2007-2013, Edita Publishing Oy, Helsinki, Finland.

Ollus, S-E. \& Simola, H. (2006), Russia in the Finnish economy, Sitra Reports 66, Edita Prima, Helsinki, Finland.

Pechlaner, H., Raich, F. \& Fischer, E. (2009), The role of tourism organizations in location management: The case of beer tourism in Bavaria, Tourism Review, 64 (2), pp. 28-40.

Ramos, P., Salazar, A. \& Gomes, J. (2000), Trends in Portuguese tourism: A content analysis of association and trade representative perspectives, International Journal of Contemporary Hospitality Management, 12 (3), pp. 409-416.

Raunio, A., Ahonen, A. \& Hagan, L. (1994), Jatkosodan historia 6, Maanpuolustuskorkeakoulun historian laitos, WSOY, Porvoo, Finland.

Regional Council of North Karelia. (2007), Pohjois-Karjalan elinkeinopoliittinen Venäjä-strategia 2015.

Regional Council of South Karelia. (2006), Etelä-Karjalan matkailustrategia 2006-

2015. 
Sharma, B. \& Dyer, P. (2009), Residents' involvement in tourism and their perceptions of tourism impacts, Benchmarking: An International Journal, 6 (3), pp. 351-371.

Silverman, D. (1997), Interpreting Qualitative Data. SAGE, London, Great-Britain.

Statistics Finland. (2009), Official statistics of Finland: Tourism statistics year 2009, Helsinki, Finland.

Statistics Finland. (2010), Official statistics of Finland: Tourism statistics May 2010, Helsinki, Finland.

Statistics Finland. (2011a), Official statistics of Finland: Labour force survey January 2011, Helsinki, Finland.

Statistics Finland. (2011b), Official statistics of Finland: Tourism statistics January 2011, Helsinki, Finland.

Stokes, R. (2005), Network-based strategy making for events tourism, European Journal of Marketing, $40(5 / 6)$, pp. 682-695.

TAK. (2005), Rajatutkimus 2004.

TAK. (2011), Rajatutkimus 2010.

Tsiotsou, R. \& Ratten, V. (2010), Future research directions in tourism marketing, Marketing Intelligence \& Planning, 28 (4), pp. 533-544.

University of Eastern Finland. (2011), Matkailijoiden päivittäinen rahankäyttö Savonlinnan seutukunnan alueella 2010. Matkailun alan opetus- ja tutkimuslaitos.

Vihavainen, T. (2006), Me ja he: Omakuva ja naapurikuva. In: Vihavainen, T. (ed.) Opas venäläisyyteen: 308-324. Otava, Keuruu, Finland.

Visit Karelia. (2011), http://www.visitkarelia.fi/In_English/Explore/North_Karelia/ Karelian_nature.iw3.

Wheelen, T. L. \& Hunger, J. D. (2006), Concepts in strategic management and business policy, 10th edition, Pearson Education, New Jersey, USA.

Wikipedia. (2011a), Pohjois-Karjalan maakunta, http://fi.wikipedia.org/wiki/PohjoisKarjalan_maakunta.

Wikipedia. (2011b), Etelä-Karjalan maakunta, http://fi.wikipedia.org/wiki/Etel\%C3\%A4Karjalan_maakunta.

Yin. R.K. (2003), Case study research: Design and methods, 3rd edition, SAGE Publications, Thousand Oaks, USA. 